\title{
Tvang i psykiatrien: Blir vi mer voktere enn pleiere?
}

En psykiatrisk sykepleier er bekymret for ivaretakelsen av pasientene på avdelingen der han jobber. Ufaglært personale arbeider i avdeling, og det har ført til en rekke uønskede episoder. Rådet for sykepleieetikk har sett på saken.

\section{Elisabeth Sveen Kjølsrud}

Leder

Rådet for sykepleieetikk

Sykepleien 2019106 (75814) (e-75814)

DOI: 10.4220/Sykepleiens.2019.75814

Rådet for sykepleieetikk får fra tid til annen henvendelser som handler om tvang i psykisk helsevern. I noen situasjoner oppstår det utfordringer og dilemmaer fordi personalet har ulik tilnærming. Rådet opplever at det i noen tilfeller går et skille mellom faglærte og ikke-faglærte.

\section{Unødvendig tvang?}


I en henvendelse til Rådet for sykepleieetikk tar en psykiatrisk sykepleier opp et dilemma om tvangsbruk. Han arbeider på en psykiatrisk akuttavdeling. Sykepleieren er bekymret for ivaretakelsen av pasientene på avdelingen og beskriver at ufagloerte $i$ høy grad blir benyttet $i$ avdeling og på skjermet avsnitt. Dette har ført til en rekke uønskede episoder med blant annet krenkelse av integritet, fratakelse av pasientens autonomi og unødig fremprovosering av kontrolltap. Sykepleieren forteller at han har varslet både den ufagloerte og ledelsen, uten at saken er blitt tatt tak $i$. Sykepleieren er engstelig for at personalet beveger seg mer $i$ retning av voktere, snarere enn pleiere. Han har støtte av sykepleiegruppen.

I våre svarbrev understreker vi i denne typen saker at vi alltid forholder oss til det innskriveren forteller oss, og gir svar ut fra det. Rådet har mulighet til å innhente svar fra alle berørte parter i saken. I mange tilfeller vet vi imidlertid at saker kan «eskalere» ved en slik metode, og vi kan risikere at mange utelater å kontakte oss.

\section{Ikke svar med to streker under}

Der er mange perspektiver og etiske retninger vi kan velge å besvare brev på, så vi må begrense oss av den grunn at innsendere sjelden $\varnothing$ nsker brev tilbake fra rådet med mange tettskrevne sider; ofte $\varnothing$ nskes det et klart svar. Rådet har sjelden et svar med to streker under, men vi oppfordrer alltid til refleksjon på arbeidsplassen for å finne gode løsninger sammen.

Når rådet svarer på henvendelser, bruker vi ofte en refleksjonsmodell. Et sentralt spørsmål vi alltid stiller oss, er hvilke verdier som er under press. Vi viser til vår yrkesetiske kodeks (www.nsf.yrkesetikk.no) og peker på sentral lovtekst.

\section{Holdninger er viktig}


A bruke tvang mot psykiatriske pasienter fører i mange tilfeller til store etiske utfordringer og dilemmaer. At personalet har et bevisst forhold til dette, er viktig, slik at bruken av tvang skjer på en mest mulig human måte. Personalets holdninger er viktige for etisk akseptabel tvangsbruk.

\section{«Å bruke tvang mot psykiatriske pasienter fører i mange tilfeller til store etiske utfordringer og dilemmaer.»}

Sykepleieren som har sendt rådet denne saken, beskriver en opplevelse av at personalgruppen beveger seg mer i retning av «vokterrollen», og rådet kan forstå bekymringen vedrørende fare for svekkelse av en nødvendig positiv holdning til pasientene.

Av sentrale elementer fra våre yrkesetiske retningslinjer (YER) (1) i denne saken, vil vi først og fremst trekke frem kapitel 2, «Sykepleieren og pasienten»: «Sykepleieren ivaretar den enkelte pasients verdighet og integritet, herunder retten til helhetlig sykepleie, retten til å være medbestemmende og retten til ikke å bli krenket.» og punkt 2.7 «Sykepleieren beskytter pasienten mot krenkende handlinger som ulovlig og unødvendig rettighetsbegrensing og tvang.»

I punkt 4 står det følgende: «Sykepleieren viser respekt for kollegers og andres arbeid, og er til st $\varnothing t t e ~ i$ vanskelige situasjoner. Dette er ikke til hinder for å ta opp brudd på faglige, etiske og kollegiale normer.»

I punkt 5.5 står dette: «Sykepleieren har rett til å forvente respekt og støtte fra kolleger og arbeidsgiver når hun/han melder fra om kritikkverdige forhold.»

Kapitel 1, punkt 1.6 i YER omhandler etisk refleksjon: «Sykepleieren anvender de yrkesetiske retningslinjer i sitt arbeid, og bidrar aktivt til etisk refleksjon i hverdagen.» 


\section{Brudd på menneskerettigheter}

Helsepersonelloven (2) peker på en plikt til å melde fra om forhold som kan medføre fare for pasientens sikkerhet. I forarbeidene til helsepersonelloven er det forutsatt at «forhold som kan medføre fare for pasientens sikkerhet» skal tolkes strengt. Situasjonen må være av en slik art at det er sannsynlig eller åpenbart at pasientens helsetilstand kan forverres, at pasienten påføres alvorlig skade. Vi som helsepersonell har dermed meldeplikt også om en kollega ikke utfører arbeidet på en forsvarlig måte.

\section{«Vi som helsepersonell har meldeplikt om en kollega ikke utfører arbeidet på en forsvarlig måte.»}

Kapitel 3 \$ 26 i psykisk helsevernforskriften (3) beskriver at bruken av tvangsmidler skal gjennomføres på en mest mulig skånsom og omsorgsfull måte. Kortvarig fastholding regnes som tvangsmiddel (\$ 25), og restriksjoner og tvang skal ikke være mer omfattende eller inngripende enn det som er strengt nødvendig for å ivareta de hensynene som ligger til grunn for tiltaket ( $\$ 15)$.

Rådet for sykepleieetikk vil også understreke at det å bli utsatt for tvang berører menneskeverdet og menneskets rett til frihet som omfattes av menneskerettighetsloven (4). Kapitel 3 i loven omhandler retten til blant annet å ikke bli utsatt for inhuman behandling. Norsk psykiatri har fått anmerkninger fra Den europeiske torturkomitéen (CPT), som har påpekt grovt brudd på menneskerettigheter innen norsk psykiatri. Vi mener konsekvensen av anmerkningen er at det påhviler et $\varnothing \mathrm{kt}$ ansvar for helsepersonell innen norsk psykiatri å være ekstra aktpågivende med ivaretakelse av mennesker underlagt psykisk helsevern. 
Avslutningsvis og som en konklusjon vil rådet berømme innsenderen av saken for årvåkenhet til det beste for pasientene. Rådet mener sykepleieren opptrer reflektert og benytter YERretningslinjene aktivt, tar opp situasjoner som kan være klanderverdige, og det han mener er etisk uforsvarlig. Sykepleieren tar også saken opp med den det gjelder og følger linjen.

Vi tenker videre at slik innsenderen beskriver pasientsituasjonen og miljøet rundt, er det grunn til å spørre om det i større grad kan reflekteres mer rundt etiske dilemmaer i avdelingen.

Spørsmål til leseren: Hvilke etiske refleksjoner praktiseres på din avdeling rundt tvang og tvangsproblematikk?

\section{Referanser}

1. Norsk Sykepleierforbund. Yrkesetiske retningslinjer for sykepleiere. Oslo: Norsk Sykepleierforbund; 2011. Tilgjengelig fra:

https://www.nsf.no/visartikkel/2193841/17036/Yrkesetiske-retningslinjer-forsykepleiere (nedlastet 04.03.2019).

2. Lov 2. juli $1999 \mathrm{nr} .64$ om helsepersonell (helsepersonelloven). Tilgjengelig fra: http://www.lovdata.no/all/tl-19990702-064-008.html (nedlastet 04.03.2019).

3. Forskrift 1. september 2017. Forskrift om etablering og gjennomføring av psykisk helsevern m.m. (psykisk helsevernforskriften) Tilgjengelig fra: https://lovdata.no/dokument/SF/forskrift/2011-12-16$\underline{1258}$ (nedlastet 04.03.2019).

4. Lov 21. mai $1999 \mathrm{nr} .30$ om styrking av menneskerettighetenes stilling i norsk rett (menneskerettsloven) Tilgjengelig fra: https://lovdata.no/dokument/NL/lov/1999-05-21-30 (nedlastet 04.02.2019). 
